\title{
Efficient Synthesis of DNA Conjugates by Strain-Promoted Azide-Cyclooctyne Cycloaddition in the Solid Phase
}

\author{
Ishwar Singh, ${ }^{*[a]}$ Colin Freeman, ${ }^{[a]}$ and Frances Heaney*[a]
}

\begin{abstract}
Keywords: Medicinal chemistry / Oligonucleotides / DNA / Solid-phase synthesis / Click reaction / Azides / Alkynes / Cycloaddition / Bioconjugation

Conjugation of ligands to DNA oligonucleotides has been achieved in the solid phase by strain-promoted azide-alkyne cycloaddition (SPAAC). The oligonucleotide, modified with a simple nonfluroinated, monocyclic octyne, efficiently forms conjugates with a range of azide dipoles with varying steric

and electronic characteristics. The reaction is clean and easily executed in a copper free environment at room temperature. It provides a variety of triazole-linked nucleic acid conjugates and is potentially useful in biotechnology and cell biology.
\end{abstract}

\section{Introduction}

The application of functionalised oligonucleotides in key areas including diagnostics and therapeutics has created the need for reliable chemical methods for postsynthetic conjugation. ${ }^{[1]}$ The high chemical stability and orthogonal reactivity of azides and alkynes has made the copper-catalysed 1,3-dipolar cycloaddition a highly attractive conjugation strategy in materials science and biotechnology. ${ }^{[2]}$ However, in spite of its vast successes, this reaction it is not ideal for oligonucleotide applications; $\mathrm{Cu}^{\mathrm{I}}$-mediated oxidative DNA degradation can be problematic, and copper ion contamination of the final product can culminate in issues of cytotoxicity and nucleic acid hydrolysis. ${ }^{[3,4]}$ Recent developments indicate that careful selection of $\mathrm{Cu}^{\mathrm{I}}$-stabilizing ligands can avoid DNA degradation and even facilitate $\mathrm{Cu}-$ promoted azide-alkyne click (CuAAC) modifications in living organisms. ${ }^{[5]}$ However, toxicity may remain an issue when oligonucleotide therapeutics are desired, and, in search of alternative bioconjugation methodologies, we and others have developed catalyst-free nitrone and nitrile oxide cycloadditions. $^{[6-11]}$ Additional, metal-free bioorthogonal conjugation strategies include Diels-Alder cycloadditions and photoinduceable cycloadditions of tetrazines or nitrile imines to alkenes. ${ }^{[12-14]}$ More recent advances in this area include strain-promoted azide-alkyne cycloadditions (SPAAC). These reactions, first observed more than 50 years ago, ${ }^{[15]}$ exploit the intrinsic ring strain of cyclooctynes. ${ }^{[16]}$ First generation substrates had relatively sluggish reactivity, and incremental improvements followed from the

[a] Department of Chemistry, National University of Ireland Maynooth, Co. Kildare, Republic of Ireland Fax: +353-1-708-3815 E-mail: ishwar.singh@nuim.ie mary.f.heaney@nuim.ie

Supporting information for this article is available on the WWW under http://dx.doi.org/10.1002/ejoc.201101045. incorporation of a ring heteroatom, steric encumberments or electron-attracting substituents; more recent rate enhancements have been observed with diaryl fused cyclooctynes and their aza analogues. ${ }^{[17-25]}$ Although azides have been the dipole of choice in most cases, more attractive kinetics have been observed with nitrile oxides. ${ }^{[26}$ Applications of strain-promoted conjugation are numerous and span diverse areas including bioimaging, ${ }^{[17,27,28]}$ quantum dot formation, ${ }^{[29]}$ peptide conjugation, ${ }^{[30]}$ drug discovery, ${ }^{[18]}$ drug delivery, ${ }^{[31]}$ synthetic chemistry ${ }^{[23]}$ and surface and materials science. ${ }^{[22,24]}$

We have previously reported the postsynthetic modification of oligonucleotides by strain-promoted nitrile oxide cycloaddition chemistry (SPNOC), ${ }^{[8]}$ and Filippov ${ }^{[32]}$ and Manoharan ${ }^{[33]}$ independently demonstrated conjugate formation by cycloaddition of azides to oligonucleotide cyclic alkynes. In their elegant studies, Filippov and Manoharan have concentrated on solution rather than solid phase conjugation. The attractions of solid-phase synthesis include the ease of purification and the possibility of automation, thus, we wished to develop resin-supported conjugation as a robust, technically accessible platform for postsynthetic oligonucleotide modification. As an additional improvement to existing methods, we wished to demonstrate the synthetic utility of a simple nonfluorinated, monocyclic octyne, in preference to an enhanced diarylcyclooctyne, as the strained alkyne partner. From a synthetic standpoint, the attractions of a cyclooctyne substrate include ease of access $^{[8]}$ and the possibility for superior kinetics with bulky azides. The reduced lipophilicity and the limited steric bulk are potentially attractive for applications in drug delivery, biomedicine and imaging where aqueous solubility and a reduced tendency to interact with hydrophobic proteins are important. Finally, advanced applications involving living systems, e.g. genetic encoding of alkynes are expected to proceed more smoothly. ${ }^{[34]}$ The objective of the current 


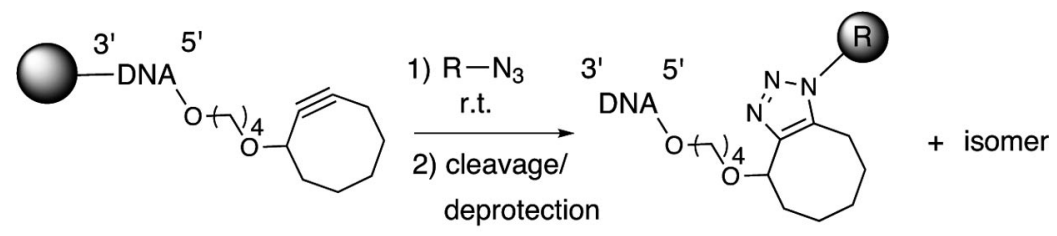

R = benzyl, cinnamyl, gluocosyl, biotin, coumarin, cholesterol, fluorescein

Scheme 1. Resin-supported postsynthetic oligonucleotide conjugation by SPAAC.

work, summarised in Scheme 1, was to develop postsynthetic oligonucleotide conjugation on the solid phase by strain-promoted cycloaddition between azide dipoles and simple monocyclic octynes.

\section{Results and Discussion}

The design and synthesis of the resin-supported DNA cyclooctynes $\mathbf{1}$ and $\mathbf{2}$ has been detailed elsewhere. ${ }^{[8]}$ We selected a range of azide partners, Figure 1, including small organic azides for proof of concept studies viz. benzyl azide (3) and cinnamyl azide (4) as well as those with potential for biomedical ${ }^{[35]}$ or imaging ${ }^{[36]}$ applications viz. glucose azide (5) as a mixture of $\alpha$ - and $\beta$-isomers, coumarin azide (6), biotin azide (7), cholesterol azide (8) and fluorescein azide (9).

Azides $\mathbf{3}$ and $\mathbf{5}$ are commercially available, and $\mathbf{4}^{[37]}$ and $6^{[38]}$ were prepared according to literature methods. 2-Azidoacetohydrazide (10), prepared from ethyl 2-azidoacetate $^{[37]}$ by reaction with hydrazine hydrate, was coupled with biotin NHS ester (11) to yield 7. The analogous 8 was accessed from a parallel route starting from cholesterol chloroformate (12, Scheme 2). Direct coupling of fluorescein methyl ester (13) and 1-azido-4-bromobutane ${ }^{[39]}$ furnished 9 in $69 \%$ yield (Scheme 3 ).

The attendant advantages of solid over solution phase chemistry ${ }^{[40]}$ guided our research, and we initially explored the reaction between CPG (controlled pore glass)-supported $\mathrm{T}_{10}$-cyclooctyne $\mathbf{1}$ with $\mathbf{3}$ and $\mathbf{4}$. Reactions were conducted on a scale employing $0.2 \mu \mathrm{m} 1$ and, in the interest of expediency, we initially employed 90 equiv. of azide in an effective dipole concentration of ca. $133 \mathrm{~mm}$. To assist with azide solubility, aqueous dimethylsulfoxide (DMSO) was selected as the solvent and reactions were conducted at room temp. (Scheme 4). Work up of the supported products 14, involving deprotection and cleavage from the resin, afforded 16, Figure 2. HPLC analysis indicated complete consumption of 1 within $30 \mathrm{~min}$ and the formation of two new products. In each case, the retention time of the products was only marginally greater than cleaved $\mathbf{1 5}$. SPAAC is not a perfect reaction and the formation of regioisomeric triazoles is deemed as an acceptable trade off for the avoidance of a copper catalyst in azide-alkyne bioconjugations. Consistent with triazole formation with little regard for regioselectivity, ${ }^{[32,35]}$ two product peaks were observed for both 16a and 16b; a minimal bias was seen for the regioisomer with slightly longer retention time.
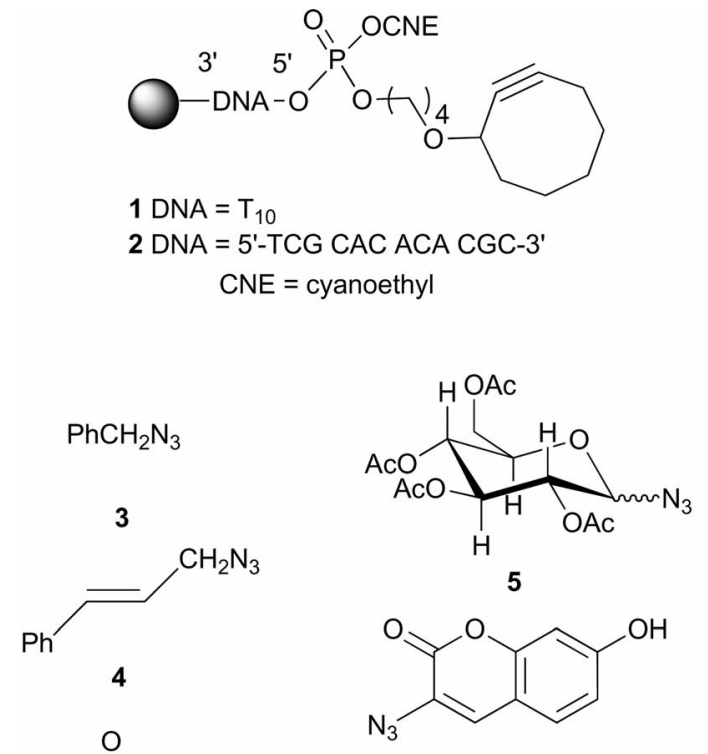<smiles>N#CCC(=O)NNC(=O)CCCCC1SCC2NC(=O)NC21</smiles><smiles>CC(C)CCC[C@H](C)[C@H]1CC[C@H]2[C@@H]3CC=C4CC(OC(=O)NNC(=O)CN)CC[C@]4(C)[C@H]3CC[C@@]21C</smiles><smiles>COC(=O)c1ccccc1-c1c2ccc(=O)cc-2oc2cc(OCCCCN)ccc12</smiles>

Figure 1. Resin supported DNA-cyclooctynes and azide reaction partners for solid-phase SPAAC.

To optimise the reaction, the ratio of the reacting dipole to the CPG-alkyne was reduced to 20:1 maintaining the di- 
<smiles>CC(C)CCC[C@H](C)[C@H]1CC[C@H]2[C@@H]3CC=C4CC(OC(=O)NNC(=O)CN)CC[C@]4(C)[C@H]3CC[C@@]21C</smiles>

Scheme 2. Synthesis of $\mathbf{8}$ and 9; i. anhydr. DMF, $\mathrm{NEt}_{3}, \mathrm{Ar}, 18$ h, room temp., $86 \%$; ii. $\mathrm{CH}_{2} \mathrm{Cl}_{2}, \mathrm{NEt}_{3}, \mathrm{Ar}, 18$ h, room temp., $34 \%$.<smiles>COC(=O)c1ccccc1-c1c2ccc(=O)cc-2oc2cc(O)ccc12</smiles>

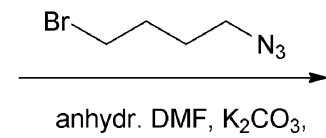<smiles>COC(=O)c1ccccc1-c1c2ccc(=O)cc-2oc2cc(OCCCCN)ccc12</smiles>

Scheme 3. Synthesis of 9.

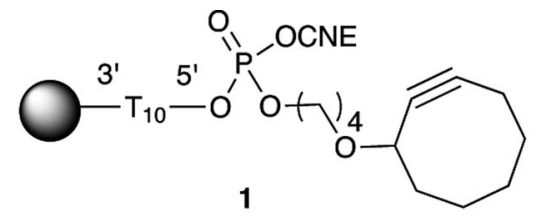

$\mathrm{RN}_{3} \quad 3 \mathrm{R}=\mathrm{PhCH}_{2}$ aq. DMSO, r.t., $30 \mathrm{~min}, 4 \mathrm{R}=\mathrm{PhCH}=\mathrm{CHCH}_{2}$

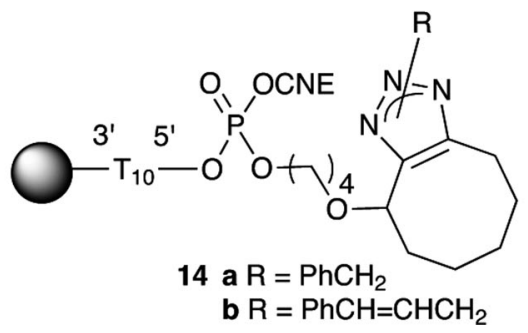

Scheme 4. Solid-supported SPAAC of $\mathbf{1}$ with 3 and 4.

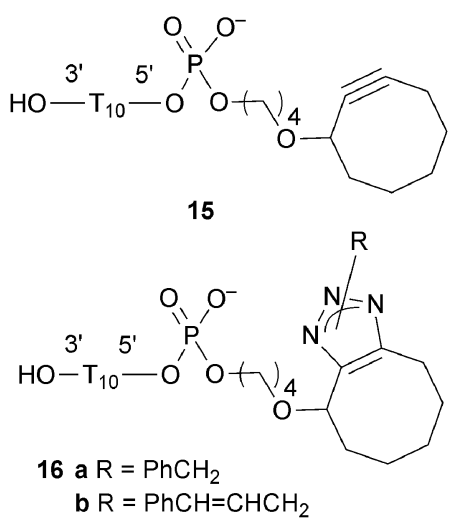

Figure 2. Structures of cleaved and deprotected oligonucleotides $\mathrm{T}_{10}$-cyclooctyne 15 and $\mathrm{T}_{10}$-conjugates $\mathbf{1 6 a}$ and $\mathbf{1 6 b}$.

pole concentration at ca. 140 mm. Aqueous DMSO (70\%) was an ideal solvent for reaction with $\mathbf{3}$, however, because of limited solubility, $90 \%$ DMSO was preferable for reaction with 4 . Gratifyingly, despite the reduced number of dipole equivalents, reaction with 3 was complete within $20 \mathrm{~min}$ as indicated by HPLC. An additional $10 \mathrm{~min}$ reaction time was required for the full consumption of starting material by 4 (Table 1). The products were readily purified by HPLC and MALDI-TOF mass spectrometry confirmed the structural integrity of the benzyl- and cinnamyl-conjugated $\mathrm{T}_{10}$-derivatives $\mathbf{1 6} \mathbf{a}$ and $\mathbf{1 6} \mathbf{b}$. The optimised experiments indicate that it is possible to compensate for the sluggish kinetics of strain-promoted cycloaddition of azides, with respect to nitrile oxide dipoles, ${ }^{[26]}$ simply by increasing the effective concentration of reacting dipole from about 30 to $140 \mathrm{~mm}^{\left[{ }^{[8]}\right.}$

Having proven that resin-supported DNA bearing a cyclooctyne is a suitable substrate for SPAAC we turned to structurally complex, yet potentially more valuable, azides 5,6 and 7 . As a consequence of limited dipole solubility in aqueous DMSO, reactions with $\mathbf{5}$ and $\mathbf{6}$ were conducted in 
Table 1. Reaction conditions for $\mathbf{1}$ with $\mathbf{3}-\mathbf{8}$.

\begin{tabular}{lllc}
\hline Azide & Solvent & Reaction time & Product \\
\hline $\mathbf{3}$ & $70 \%$ aq. DMSO & $20 \mathrm{~min}$ & $\mathbf{1 6 a}$ \\
$\mathbf{4}$ & $90 \%$ aq. DMSO & $30 \mathrm{~min}$ & $\mathbf{1 6 b}$ \\
$\mathbf{5}$ & $\mathrm{DMSO}$ & $4 \mathrm{~h}$ & $\mathbf{1 6 c}$ \\
$\mathbf{6}$ & $\mathrm{DMSO}$ & $25 \mathrm{~min}$ & $\mathbf{1 6 d}$ \\
$\mathbf{7}$ & $90 \%$ aq. DMSO & $4 \mathrm{~h}$ & $\mathbf{1 6 e}$ \\
$\mathbf{8}$ & $\mathrm{CHCl}_{3}$ & $16 \mathrm{~h}$ & $\mathbf{1 6 f}$ \\
\hline
\end{tabular}

the absence of water, and aqueous DMSO ( $90 \%$ ) was effective for solubilisation of 7 . Reactions were conducted at room temp., with 20 equiv. of dipole. HPLC analysis of the cleaved reaction products indicate that a reaction time of between $25 \mathrm{~min}$ and $4 \mathrm{~h}$ was required for complete consumption of 1 (Table 1). For the conjugates, the peak splitting of $\mathbf{1 6 c}$, arising from the reaction with $\mathbf{5}$, is consistent with a mixture of anomers in the starting azide. Products arising from 6 and 7, 16d and 16e, respectively, are represented by two sharp peaks. The DNA conjugated triazoles were easily separated from impurities in the starting material. MALDI-TOF mass analysis of $\mathbf{1 6 c}$ indicated deacetylation of the glucose moiety during the standard protocol for cleavage of the oligonucleotide from the resin; mass data confirmed the structural integrity of $\mathbf{1 6 d}$ and $\mathbf{1 6 e}$ (Figure 3 ).
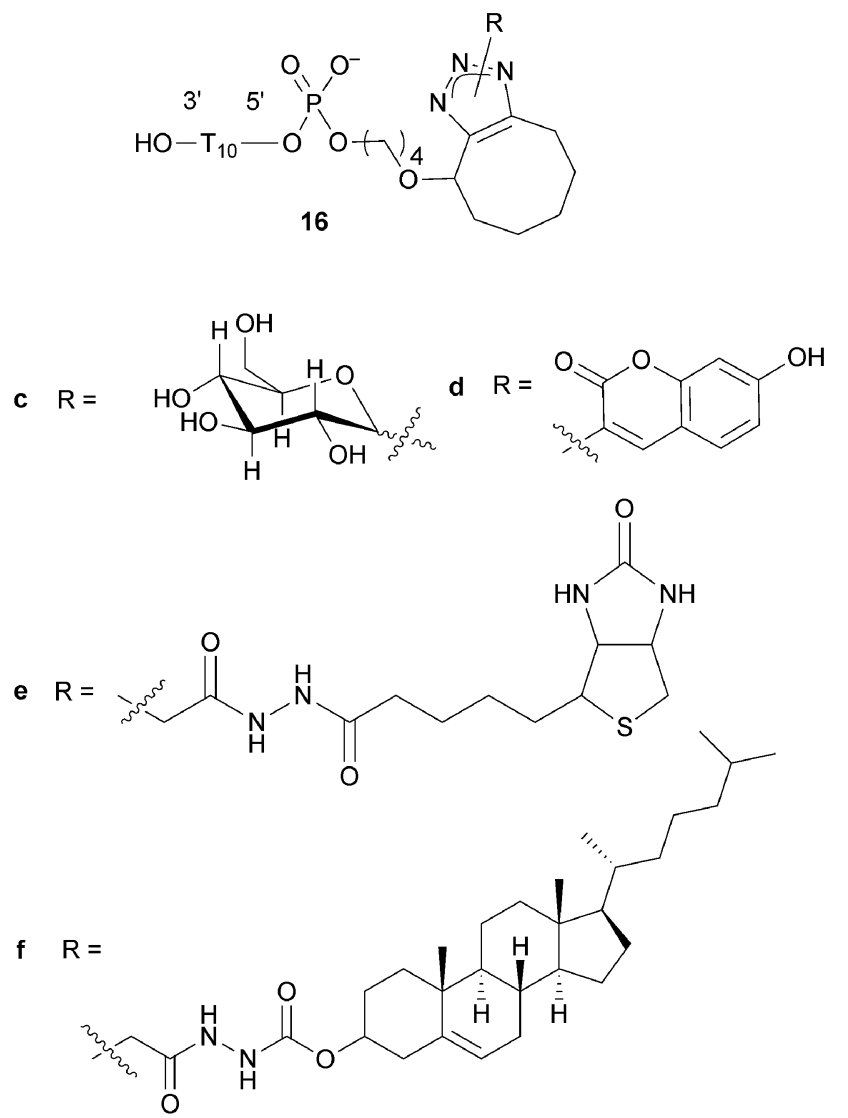

Figure 3. Triazole-ligated conjugates $\mathbf{1 6 c}-\mathbf{f}$, prepared by solid-supported SPAAC.

It is reported that strain-promoted cycloaddition is relatively insensitive to the electronic structure of the azide ${ }^{[19]}$ and we judge the increased steric demands of 5 and 7, com- pared to 3, 4 and 6 , to account for the fall in the rate of reaction (Table 1). However, it is significant that the rates of formation of $16 \mathbf{a}-\mathbf{e}$, by cycloaddition to cyclooctyne, compare favourably with those observed for conjugates formed by cycloaddition to RNAs bearing strained alkynes of enhanced reactivity, viz. dibenzocyclooctyne. ${ }^{[32,33]}$

It is known that lipid conjugation facilitates both cellular uptake and intracellular delivery of oligonucleotides and so provides hope for a nontoxic alternative to the cationic lipophilic or polymeric siRNA delivery systems, ${ }^{[41,42]}$ and we wished to extend the scope of the SPAAC reaction to include steroidal examples. However, despite the advances in methodologies for the postsynthetic modification of oligonucleotides, the synthesis of steroidal conjugates remains nontrivial. In two recent reports, CuAAC modifications have been demonstrated. In one, conjugation at the monomeric level preceded oligonucleotide synthesis, ${ }^{[43]}$ and in the other, microwave-assisted conjugation to a resin-supported oligonucleotide-alkyne has been reported $\left(60^{\circ} \mathrm{C}\right.$, $45 \mathrm{~min}) .{ }^{[41]}$ For pharmaceutical applications the minimal acceptable copper concentration in the final product is $15 \mathrm{ppm},{ }^{[44]}$ thus syntheses avoiding copper catalysis have obvious advantages. Solubilisation of $\mathbf{8}$ was optimal in $\mathrm{CHCl}_{3}$, which was employed as the solvent for its reaction with $1, \mathrm{CHCl}_{3}$ was also used in place of the traditional $\mathrm{MeCN}$ for washing excess reagents from the resin during the work up. HPLC analysis of the raw products indicates complete consumption of $\mathbf{1}$ after $16 \mathrm{~h}$ at room temp. (Table 1). Due to the lipophilicity of the steroidal moiety, HPLC analysis of the crude products and separation of the cholesterol conjugates (16f, Figure 3 ) were performed on a Spherisorb C8 column.

Having verified the potential of resin-supported $\mathbf{1}$ as a click partner with azide dipoles, we wished to demonstrate compatibility with the CPG-supported dodecamer 2 (DNA $=5^{\prime}-\mathrm{TCG}$ CAC ACA CGC-3'), which carries all four nucleobases with their standard protecting groups. Exposure of 2 to 3 or 4 (20 equiv., $140 \mathrm{~mm}$ ) in aqueous DMSO (50\%) resulted in the formation of conjugates $\mathbf{1 7} \mathbf{a}$ and $\mathbf{1 7} \mathbf{b}$ (Figure 4) as judged by HPLC. As observed for all the $\mathrm{T}_{10}$-cyclooctyne-azide conjugates 16, except 16f, similarities in the polarity characteristics of the parent $\mathbf{1 5 / 1 8}$ and the conjugated oligonucleotides $\mathbf{1 6 a - e / 1 7 a - b}$ resulted in HPLC profiles with relatively little difference between the retention time of reacted and unreacted cyclooctynes. However, coinjection of a reference sample of $\mathbf{1 8}$ with the reaction products indicated almost complete conversion to the conjugates $\mathbf{1 7} \mathbf{a}$ and $\mathbf{1 7 b}$ after $20 \mathrm{~min}$ at room temperature. As expected, the reactions proceeded almost without regiochemical preference and MALDI-TOF mass spectrometry confirmed the structural integrity of the new conjugates. Conjugation to 7 required $4 \mathrm{~h}$ to reach completion in aqueous DMSO, whereas reaction with $\mathbf{8}$ progressed smoothly in $\mathrm{CHCl}_{3}$ after agitation overnight at room temp. (Table 2). In each case, HPLC analysis confirmed virtually full consumption of 2. Purified samples of the regioisomeric triazole conjugates $\mathbf{1 7} \mathbf{c}$ and $\mathbf{1 7 d}$ were obtained following separation by HPLC. 


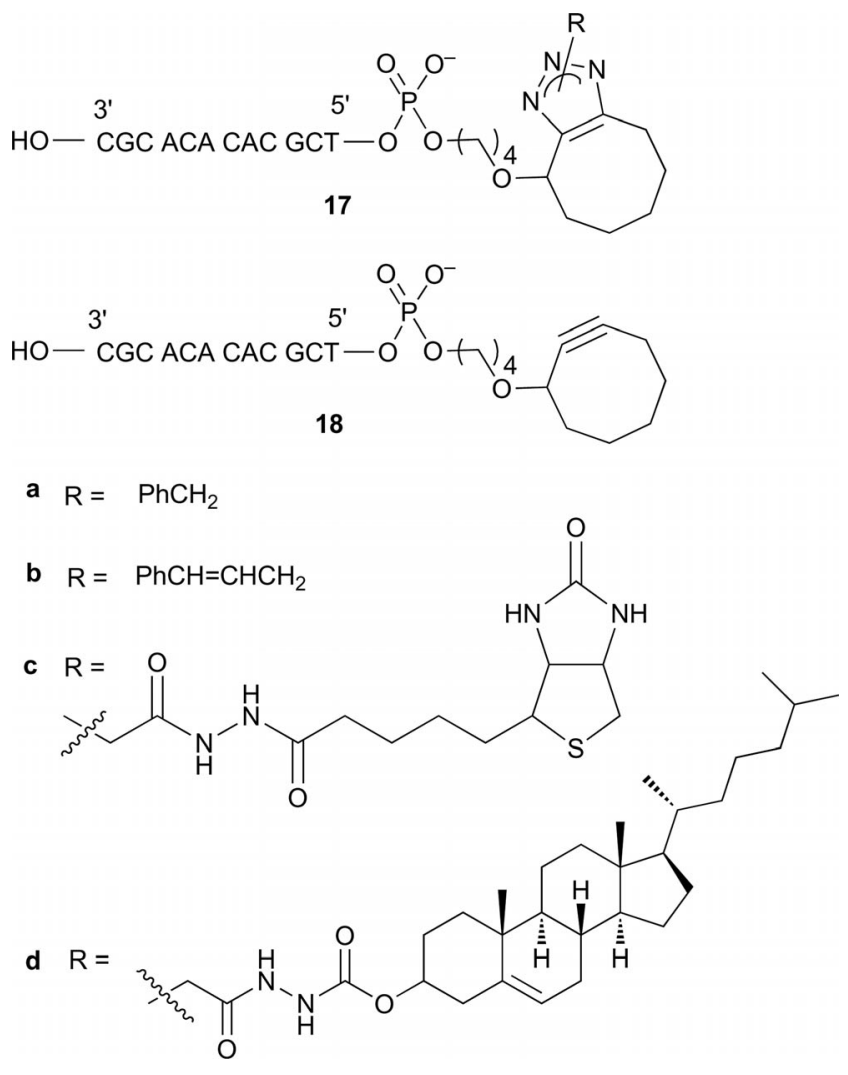

Figure 4. Triazole-ligated DNA-conjugates $\mathbf{1 7 a - d}$ prepared by solid-supported SPAAC.

Table 2. Reaction conditions for 2 with 3, 4, 7, 8 and 9.

\begin{tabular}{lllc}
\hline Azide & Solvent & Reaction time & Product \\
\hline $\mathbf{3}$ & $50 \%$ aq. DMSO & $30 \mathrm{~min}$ & $\mathbf{1 7 a}$ \\
$\mathbf{4}$ & $50 \%$ aq. DMSO & $30 \mathrm{~min}$ & $\mathbf{1 7 b}$ \\
$\mathbf{7}$ & $90 \%$ aq. DMSO & $4 \mathrm{~h}$ & $\mathbf{1 7 c}$ \\
$\mathbf{8}$ & $\mathrm{CHCl}_{3}$ & $16 \mathrm{~h}$ & $\mathbf{1 7 d}$ \\
$\mathbf{9}$ & $90 \%$ aq. DMF & $16 \mathrm{~h}$ & $\mathbf{1 7 e}$ \\
$\mathbf{9}^{[\mathbf{a}]}$ & $90 \%$ aq. DMF & $16 \mathrm{~h}$ & $\mathbf{1 7 f}$
\end{tabular}

[a] This reaction was conducted in the solution phase.
Fluorescent tags have largely taken over from radioactive labels in unravelling molecular pathways and we wished to demonstrate the potential of resin-supported SPAAC with 9 to furnish fluorescent oligonucleotide probes. A range of solvents, including aqueous $N, N$-dimethylformamide (DMF), DMSO and $\mathrm{CHCl}_{3}(90 \%$ ), were selected for experiments between 9 and $\mathbf{2}$. In all cases, following washing of excess reagents, the resin-supported products retained an intense yellow colour and displayed fluorescence. However, during the cleavage/deprotection protocol, the colour began to fade before disappearing completely. We supposed that this concurred with a prevalence of the nonfluorescent lactone form of the hydrolysed ester. ${ }^{[4]}$ Although the HPLC traces of the crude reaction products indicated significant consumption of the starting material $(\approx 85-100 \%)$ and the emergence of a double peak characteristic of regioisomeric triazole conjugates, MALDI-TOF mass analysis of a purified product sample found $\mathrm{m} / \mathrm{z}=4262$, which is consistent with the spirolactone structure 17e (Figure 5).

The failure of the fluorescein methyl ester to remain inert under the standard ammomium hydroxide mediated cleavage/deprotection protocol of solid phase oligonucleotide synthesis suggested that conjugation to $\mathbf{9}$ may be more suited to solution chemistry. DNA-cyclooctyne 18, obtained from 2 following deprotection and cleavage from the resin, was exposed to an aqueous DMF solution of $\mathbf{9}$. The reaction progressed cleanly, judged by HPLC, however, even after $18 \mathrm{~h}$ at room temp. consumption of the starting oligonucleotide was modest $(\approx 35 \%)$. This rose to an acceptable $80 \%$ by doubling the number of azide equivalents. The identity and integrity of the conjugate, which retained the yellow colour characteristic of molecules incorporating a tetracyclic fluorescein skeleton, was confirmed as $\mathbf{1 7 f}$ by HPLC and MALDI-TOF mass analysis $(\mathbf{1 7 f} \mathrm{m} / \mathrm{z}$ requires 4278; found 4277).

\section{Conclusions}

We have demonstrated that SPAAC in the solid phase offers a robust and reliable method for oligonucleotide con-<smiles>O=C1OC2(c3ccc(O)cc3Oc3cc(OCCCCn4nnc5c4CCCCCC5OCCCCOP(=O)([O-])O[Na])ccc32)c2ccccc21</smiles><smiles>COC(=O)c1ccccc1-c1c2ccc(=O)cc-2oc2cc(OCCCCn3nnc4c3CCCCCC4OCCCCOP(=O)(O)O[Na])ccc12</smiles>

Figure 5. Triazole-ligated 17e and $\mathbf{1 7 f}$ prepared from the reaction of $\mathbf{9}$ with $\mathbf{2}$ or in the solution phase with DNA-cyclooctyne 18, respectively. 
jugation. It has been shown that, for reaction in the solid phase, it is not necessary to have an alkyne partner with enhanced reactivity and that a simple DNA-cyclooctyne is a suitable substrate for bioconjugation. Our success with the monocyclic strained alkyne will be deemed beneficial by those interested in conjugates of large azido partners or conjugates with reduced lipophilicity. Compatibility is demonstrated with azides of varying steric bulk and electronic demands, including biotin and cholesterol, the conjugates of which have potential application in cell biology and drug delivery. In circumstances where the azido partner carries functionalities incompatible with solid phase chemistry, it has been demonstrated that conjugation to DNA-cyclooctynes can be efficiently executed in solution.

\section{Experimental Section}

General: Analytical TLC was performed on precoated $(250 \mu \mathrm{m})$ silica gel 60 F-254 plates from Merck. All plates were visualised by UV irradiation and/or staining with $5 \% \mathrm{H}_{2} \mathrm{SO}_{4}$ in ethanol followed by heating. Flash chromatography was performed using silica gel $32-63 \mu \mathrm{m}, 60 \AA$. Mass analysis was performed with a LASER-TOF LT3 or Applied Biosystem Voyager with 3-hydroxypicolinic acid or $2^{\prime}, 4^{\prime}, 6^{\prime}$-trihydroxyacetophenone as matrix or recorded by Metabion, Germany. NMR spectra were obtained with a Bruker instrument at $25^{\circ} \mathrm{C}\left({ }^{1} \mathrm{H}\right.$ at $300 \mathrm{MHz} ;{ }^{13} \mathrm{C}$ at $\left.75 \mathrm{MHz}\right)$. Chemical shifts are reported in ppm downfield from TMS as standard. NMR spectra are recorded in $\mathrm{CDCl}_{3}$ unless otherwise stated. UV analysis was performed with a Jasco V-630BIO spectrophotometer at $25^{\circ} \mathrm{C}$. HPLC was carried out with a Gilson instrument equipped with a diode array detector and a Nucleosil C18 column $(4.6 \times 250 \mathrm{~mm})$ or a Phenonmex C8 column $(4.6 \times 250 \mathrm{~mm})$; a Dionex Ultimate 3000 instrument equipped with a Clarity Oligo RP C18 (4.6× $250 \mathrm{~mm})$ or a Spherisorb C8 $(4.6 \times 250 \mathrm{~mm})$ column was also used. DNA was desalted with illustra ${ }^{\mathrm{TM}}$ NAP $^{\mathrm{TM}}-10$ Sephadex $^{\mathrm{TM}}$ G-25 DNA grade columns purchased from GE Healthcare.

2-Azidoacetohydrazide (10): To a solution of ethyl 2-azidoacetate ${ }^{[37]}$ $(2.0 \mathrm{~g}, 15.5 \mathrm{mmol})$ in ethanol $(10 \mathrm{~mL})$ was added hydrazine hydrate $(1.3 \mathrm{~mL}, 25.3 \mathrm{mmol})$. The mixture was allowed to stir at room temperature for $2 \mathrm{~h}$ after which TLC analysis $\left(\mathrm{CH}_{2} \mathrm{Cl}_{2} / \mathrm{MeOH}, 9: 1\right)$ indicated complete consumption of the starting material. Following removal of the solvent under reduced pressure, the crude product was purified by flash column chromatography $\left(\mathrm{CH}_{2} \mathrm{Cl}_{2} / \mathrm{MeOH}\right.$, 9:1) to yield a colourless oil $(1.6 \mathrm{~g}, 90 \%) .{ }^{1} \mathrm{H}$ NMR: $\delta=8.14$ (br. s, $1 \mathrm{H}), 4.06$ (br. s, $2 \mathrm{H}$ ), 4.01 (s, $2 \mathrm{H})$ ppm. ${ }^{13} \mathrm{C}$ NMR: $\delta=167.5$, 51.6 ppm. HRMS (ESI): calcd. for $\mathrm{C}_{2} \mathrm{H}_{5} \mathrm{~N}_{5} \mathrm{ONa}[\mathrm{M}+\mathrm{Na}]^{+}$ 138.0386; found 138.0390.

$N^{\prime}$-(2-Azidoacetyl)-5-(2-oxohexahydro-1 $H$-thieno[3,4- $d$ ]imidazol-4yl)pentanehydrazide (7): To a solution of $\mathbf{1 1}^{[46]}(870 \mathrm{mg}, 2.55 \mathrm{mmol})$ and 10 (352 mg, $3.06 \mathrm{mmol})$ in anhydrous DMF (20 mL) was added triethylamine $(1.5 \mathrm{~mL}, 20.4 \mathrm{mmol})$. The resulting mixture was stirred overnight at room temperature under an argon atmosphere. Following removal of particulate matter by filtration, the filtrate was evaporated to yield the crude product as a white solid, which was washed with $\mathrm{CH}_{2} \mathrm{Cl}_{2}(5 \times 10 \mathrm{~mL})$ to yield pure 7 (745 mg, 86\%). ${ }^{1} \mathrm{H}$ NMR ([D $]$ DMSO): $\delta=10.05$ (br. s, $\left.1 \mathrm{H}\right), 9.86$ (s, $1 \mathrm{H}), 6.43$ (s, $1 \mathrm{H}), 6.36$ (s, $1 \mathrm{H}), 4.33-4.29(\mathrm{~m}, 1 \mathrm{H}), 4.16-4.12$ $(\mathrm{m}, 1 \mathrm{H}), 3.89(\mathrm{~s}, 2 \mathrm{H}), 3.14-3.07(\mathrm{~m}, 1 \mathrm{H}), 2.86-2.80(\mathrm{~m}, 1 \mathrm{H})$, 2.60-2.56 (m, $1 \mathrm{H}), 2.14(\mathrm{t}, J=7.2 \mathrm{~Hz}, 2 \mathrm{H}), 1.64-1.30(\mathrm{~m}, 6 \mathrm{H})$ ppm. ${ }^{13} \mathrm{C}$ NMR ([D $]$ DMSO): $\delta=170.9,166.3,162.7,61.0,59.2$,
55.4, 49.3, 32.9, 28.0, 27.9, 25.0 ppm. HRMS (ESI): calcd. for $\mathrm{C}_{12} \mathrm{H}_{20} \mathrm{~N}_{7} \mathrm{O}_{3} \mathrm{~S}[\mathrm{M}+\mathrm{H}]^{+}$342.1343; found 342.1352.

$(8 S, 9 S, 10 R, 13 R, 14 S, 17 R)-10,13-D i m e t h y l-17-I(R)-6$-methylheptan2-yl]-2,3,4,7,8,9,10,11,12,13,14,15,16,17-tetradecahydro- $1 H$-cyclopenta[a]phenanthren-3-yl 2-(2-Azidoacetyl)hydrazinecarboxylate (8): To a solution of $\mathbf{1 0}(0.62 \mathrm{~g}, 5.39 \mathrm{mmol})$ and triethylamine $(620 \mu \mathrm{L})$ in $\mathrm{CH}_{2} \mathrm{Cl}_{2}(50 \mathrm{~mL})$ was added a solution of $\mathbf{1 2}(2.00 \mathrm{~g}, 4.45 \mathrm{mmol})$ in $\mathrm{CH}_{2} \mathrm{Cl}_{2}(100 \mathrm{~mL})$. The resulting mixture was stirred at room temperature overnight. The solvent was removed under reduced pressure and the crude product was purified by flash column chromatography (hexane/ethyl acetate, 7:3) to yield a white solid (800 mg, 34\%). ${ }^{1} \mathrm{H}$ NMR: $\delta=8.19$ (s, $\left.1 \mathrm{H}\right), 6.75$ (s, $\left.1 \mathrm{H}\right), 5.38(\mathrm{~d}$, $J=5.1 \mathrm{~Hz}, 1 \mathrm{H}), 4.62-4.51(\mathrm{~m}, 1 \mathrm{H}), 4.08(\mathrm{~s}, 2 \mathrm{H}), 2.40-2.33(\mathrm{~m}$, $2 \mathrm{H}), 2.03-0.85(\mathrm{~m}, 38 \mathrm{H}), 0.68(\mathrm{~s}, 3 \mathrm{H}) \mathrm{ppm} .{ }^{13} \mathrm{C}$ NMR: $\delta=166.2$, $155.5,139.3,123.0,56.7,56.1,51.5,50.0,42.3,39.7,39.5,38.2$, $36.9,36.5,36.2,35.8,31.9,31.8,28.2,28.0,27.9,24.3,23.8,22.8$, 22.6, 21.0, 19.3, 18.7, 11.9 ppm. $\mathrm{C}_{30} \mathrm{H}_{49} \mathrm{~N}_{5} \mathrm{O}_{3}$ (527.38): C 68.27, H9.36, N 13.27; found C 68.02, H 9.39, N 13.33.

Methyl 2-[6-(4-Azidobutoxy)-3-oxo-3H-xanthen-9-yl]benzoate (9): To a solution of 1-azido-4-bromobutane ${ }^{[39]}(270 \mathrm{mg}, 1.26 \mathrm{mmol})$ in anhydrous DMF (5 mL) was added $13^{[47]}(314 \mathrm{mg}, 0.90 \mathrm{mmol})$ and potassium carbonate $(170 \mathrm{mg}, 1.23 \mathrm{mmol})$. The mixture was heated to $70{ }^{\circ} \mathrm{C}$ under an argon atmosphere for $2 \mathrm{~h}$ after which TLC analysis $\left(\mathrm{CH}_{2} \mathrm{Cl}_{2} / \mathrm{MeOH}, 9: 1\right)$ indicated complete reaction. The mixture was diluted with EtOAc $(20 \mathrm{~mL})$ and washed with water $(3 \times$ $10 \mathrm{~mL}$ ). The organic layer was dried with $\mathrm{MgSO}_{4}$, and the solvent was removed under vacuum to yield an orange-brown solid. This was washed with hexane $(6 \times 10 \mathrm{~mL})$ to remove excess starting azide, yielding the product as an orange-brown solid, which was used without further purification (276 mg, 69\%). ${ }^{1} \mathrm{H}$ NMR: $\delta=8.25(\mathrm{~d}$, $J=7.5 \mathrm{~Hz}, 1 \mathrm{H}), 7.77-7.65(\mathrm{~m}, 2 \mathrm{H}), 7.31(\mathrm{~d}, J=7.2 \mathrm{~Hz}, 1 \mathrm{H})$, $6.95-6.83(\mathrm{~m}, 3 \mathrm{H}), 6.73(\mathrm{dd}, J=2.1,8.7 \mathrm{~Hz}, 1 \mathrm{H}), 6.54(\mathrm{dd}, J=$ $1.8,9.6 \mathrm{~Hz}, 1 \mathrm{H}), 6.45(\mathrm{~d}, J=1.8 \mathrm{~Hz}, 1 \mathrm{H}), 4.10(\mathrm{t}, J=6.0 \mathrm{~Hz}, 2$ H), 3.64 (s, $3 \mathrm{H}), 3.39$ (t, $J=6.6 \mathrm{~Hz}, 2 \mathrm{H}) 1.98-1.73(\mathrm{~m}, 4 \mathrm{H}) \mathrm{ppm}$. ${ }^{13}$ C NMR: $\delta=185.5,165.6,163.3,158.9,154.2,150.3,134.5,132.7$, $131.1,130.5,130.2,130.2,129.7,129.7,128.9,117.4,114.8,113.6$, 105.6, 100.8, 68.1, 52.3, 51.03, 26.2, 25.6 ppm. HRMS (ESI): calcd. for $\mathrm{C}_{25} \mathrm{H}_{22} \mathrm{~N}_{3} \mathrm{O}_{5}[\mathrm{M}+\mathrm{H}]^{+}$444.1554; found 444.1574.

General Procedure for the Azide Click Reactions on 1. Preparation of Conjugates 16: To solid-supported $\mathbf{1}^{[8]}(0.2 \mu \mathrm{mol})$ in an Eppendorf tube was added a solution of the azide in DMSO $(20 \mu \mathrm{L}$ of a $200 \mathrm{~mm}$ stock solution, $4 \mu \mathrm{mol}, 20$ equiv.) and the final volume was adjusted to $30 \mu \mathrm{L}$ with DMSO and water according to the solubility of azide (Table 1). The mixture was agitated at room temperature. After completion of the conjugation (Table 1), as monitored by HPLC, the supernatant liquid was removed by syringe and the CPG was washed with $\mathrm{CH}_{3} \mathrm{CN}(5 \times 300 \mu \mathrm{L})$ and $\mathrm{H}_{2} \mathrm{O}(5 \times$ $300 \mu \mathrm{L}$ ). In the reaction with $\mathbf{8}$, chloroform was used as the reaction solvent and in place of $\mathrm{CH}_{3} \mathrm{CN}$ during the work up. Cleavage from the resin, deprotection (method i) and HPLC analysis (conditions A) followed according to the procedures described below.

General Procedures for Deprotection and Cleavage of DNA on Solid Phase: For analytical purposes a portion of the DNA was deprotected and cleaved from the CPG by incubating the CPG-DNA under conditions i) $28 \%$ aqueous $\mathrm{NH}_{4} \mathrm{OH}(500 \mu \mathrm{L})$ at $25^{\circ} \mathrm{C}$ for 30 min (for substrates 16), or ii) $28 \%$ aqueous $\mathrm{NH}_{4} \mathrm{OH}(500 \mu \mathrm{L}$ ) diluted to $750 \mu \mathrm{L}$ with $\mathrm{EtOH}$ at $25^{\circ} \mathrm{C}$ for $24 \mathrm{~h}$ (for substrates 17). $\mathrm{NH}_{4} \mathrm{OH}$ was evaporated using a concentrator. The CPG was washed with $\mathrm{H}_{2} \mathrm{O}(3 \times 150 \mu \mathrm{L}$ aliquots $)$, all solutions and washings were combined to afford an aqueous solution of DNA, which was analysed and purified by reversed-phase HPLC. 
General Methods for HPLC Analysis and Purification of Oligonucleotide Conjugates: DNA cycloaddition products $\mathbf{1 6}$ and $\mathbf{1 7}$ were analyzed by reverse-phase HPLC under either conditions A (for products 16) or B (for products 17). Conditions A: $20 \mu \mathrm{L}$ injection loop. Buffer A: 0.1 м TEAAc, pH 7.5, 1\% (v/v) MeCN; Buffer B: 0.1 м TEAAc, pH 7.5, $80 \%(\mathrm{v} / \mathrm{v}) \mathrm{MeCN}$. Gradient for 16a-e: 0 $3 \mathrm{~min}, 5 \% \mathrm{~B}$; 3-23 min, $5 \rightarrow 95 \%$ B. Gradient for 16f: 0-3 min 10\% B, $3-13,10 \rightarrow 95 \%$ B. Flow rate: $1.0 \mathrm{~mL} / \mathrm{min}$. Detection at $260 \mathrm{~nm}$. Column: Clarity Oligo RP C18 $(4.6 \times 250 \mathrm{~mm})$ for $16 a-e$ and a Spherisorb C8 $(4.6 \times 250 \mathrm{~mm})$ column for 16f. Conditions B: $200 \mu \mathrm{L}$ injection loop. Buffer A: 0.1 м TEAAc, $\mathrm{pH} 7.5,5 \%$ (v/v) MeCN; Buffer B: 0.1 м TEAAc, pH 7.5, 65\% (v/v) MeCN. Gradient: $0-4.3 \mathrm{~min}, 5 \% \mathrm{~B} ; 4.3-16.6 \mathrm{~min}, 5 \rightarrow 100 \% \mathrm{~B}$. Flow rate: $1.0 \mathrm{~mL} /$ min. Detection at $260 \mathrm{~nm}$. Column: Nucleosil C18 column $(4.6 \times$ $250 \mathrm{~mm})$ for $\mathbf{1 7 a}-\mathbf{c}, \mathbf{e}, \mathbf{f}$ or Phenonmex C8 column $(4.6 \times 250 \mathrm{~mm})$ for 17d.

General Procedure for Click Reactions on 2 with 3, 4 and 7. Preparation of Conjugates 17a-c: To solid-supported $\mathbf{2}^{[8]}(0.12 \mu \mathrm{mol})$ in an eppendorf tube was added a solution of the azide $(10 \mu \mathrm{L}$ of a $240 \mathrm{~mm}$ stock solution in DMSO, $2.4 \mu \mathrm{mol}, 20$ equiv.) and the volume was adjusted to $20 \mu \mathrm{L}$ with DMSO and water according to the solubility of the azide (Table 2). The mixture was agitated at room temperature. After completion of the conjugation (Table 2), as monitored by HPLC, the CPG was washed with $\mathrm{CH}_{3} \mathrm{CN}$ $(5 \times 300 \mu \mathrm{L})$ and $\mathrm{H}_{2} \mathrm{O}(1 \times 300 \mu \mathrm{L})$. In the case of $17 \mathrm{c}$, DMSO was used instead of $\mathrm{CH}_{3} \mathrm{CN}$ during the work up. Cleavage from the resin, deprotection (method ii) and HPLC analysis (conditions B) followed according to the procedures described above.

Procedure for Click Reaction between 2 and 8. Preparation of Cholesterol Conjugate 17d: To solid-supported $\mathbf{2}^{[8]}(0.08 \mu \mathrm{mol})$ in an eppendorf tube was added a solution of $8(15 \mu \mathrm{L}$ of a $107 \mathrm{~mm}$ stock solution in $\mathrm{CHCl}_{3}, 1.6 \mu \mathrm{mol}, 20$ equiv.) and the resulting mixture was agitated at room temperature overnight. After completion of the conjugation, the CPG was washed with $\mathrm{CHCl}_{3}(5 \times 300 \mu \mathrm{L})$, $\mathrm{CH}_{3} \mathrm{CN}(1 \times 300 \mu \mathrm{L})$ and $\mathrm{H}_{2} \mathrm{O}(1 \times 300 \mu \mathrm{L})$. Cleavage from the resin, deprotection (method ii) and HPLC analysis (conditions $\mathrm{B}$ ) followed according to the procedures described above.

Procedure for Click Reaction between 2 and 9. Preparation of Fluorescein Conjugate 17e: To solid-supported $2^{[8]}(0.08 \mu \mathrm{mol})$ in an eppendorf tube was added a solution of $9(18 \mu \mathrm{L}$ of an $89 \mathrm{~mm}$ stock solution in $\mathrm{CHCl}_{3}, 1.6 \mu \mathrm{mol}, 20$ equiv.) and $\mathrm{H}_{2} \mathrm{O}(2 \mu \mathrm{L})$ and the resulting mixture was agitated at room temperature overnight. After completion of the conjugation, the $\mathrm{CPG}$ was washed with $\mathrm{CHCl}_{3}(5 \times 300 \mu \mathrm{L}), \mathrm{CH}_{3} \mathrm{CN}(1 \times 300 \mu \mathrm{L})$ and $\mathrm{H}_{2} \mathrm{O}(1 \times 300 \mu \mathrm{L})$. Cleavage from the resin, deprotection (method ii) and HPLC analysis (conditions B) followed according to the procedures described above.

Procedure for Click Reaction in the Solution Phase between 18 and 9. Preparation of Fluorescein Conjugate 17f: Following deprotection and cleavage from the resin of $\mathbf{2}$ (method ii), an aqueous solution of $18(125 \mu \mathrm{L}, 200 \mu \mathrm{M}, 0.025 \mu \mathrm{mol})$ was evaporated to dryness under vacuum. To this was added a solution of $9(9.0 \mu \mathrm{L}$ of a $112 \mathrm{~mm}$ stock solution in DMF, $1.0 \mu \mathrm{mol}, 40$ equiv.) and $\mathrm{H}_{2} \mathrm{O}(0.5 \mu \mathrm{L})$. The resulting solution was agitated overnight at room temperature. $\mathrm{H}_{2} \mathrm{O}$ $(200 \mu \mathrm{L})$ was added and this solution was washed with EtOAc $(10 \times 300 \mu \mathrm{L})$ to remove the excess azide. Any remaining EtOAc was removed under vacuum and the resulting aqueous solution was analysed and purified by reversed-phase HPLC (conditions B) to furnish $\mathbf{1 7 f}$.

Supporting Information (see footnote on the first page of this article): Copies of ${ }^{1} \mathrm{H}$ and ${ }^{13} \mathrm{C}$ NMR spectra, HPLC data and MALDI-TOF MS data.

\section{Acknowledgments}

Financial support from the Science Foundation of Ireland (Programme code 05/PICA/B838) is acknowledged. C. F. is grateful to NUI Maynooth and the Irish Research Council Science and Engineering for receipt of an Embark Postgraduate Research Scholarship (Programme code RS/2007/48).

[1] Y. Singh, P. Murat, E. Defrancq, Chem. Soc. Rev. 2010, 39, 2054-2070.

[2] J. Lahann (Ed.), Click Chemistry for Biotechnology and Materials Science, Wiley, Chichester, United Kingdom, 2009.

[3] J. Gierlich, G. A. Burley, P. M. E. Gramlich, D. M. Hammond, T. Carell, Org. Lett. 2006, 8, 3639-3642.

[4] L. M. Gaetke, C. K. Chow, Toxicology 2003, 189, 147-163; A. J. Link, D. A. Tirrell, J. Am. Chem. Soc. 2003, 125, 11164 11165.

[5] D. Soriano del Amo, W. Wan, H. Jiang, C. Besanceney, A. C. Yan, M. Levy, Y. Liu, F. L. Marlow, P. Wu, J. Am. Chem. Soc. 2010, 132, 16893; T. R. Chan, R. Hilgraf, K. B. Sharpless, V. V. Fokin, Org. Lett. 2004, 6, 2853.

[6] X. Ning, R. P. Temming, J. Dommerholt, J. Guo, D. B. Ania, M. F. Debets, M. A. Wolfert, G.-J. Boons, F. L. van Delft, $A n$ gew. Chem. 2010, 49, 3065-3068.

[7] I. Singh, F. Heaney, Org. Biomol. Chem. 2010, 8, 451-456.

[8] I. Singh, F. Heaney, Chem. Commun. 2011, 47, 2706-2708.

[9] I. Singh, J. S. Vyle, F. Heaney, Chem. Commun. 2009, 3276 3278.

[10] K. Gutsmiedl, D. Fazio, T. Carell, Chem. Eur. J. 2010, 16, 6877-6883.

[11] K. Gutsmiedl, C. T. Wirges, V. Ehmke, T. Carell, Org. Lett. 2009, 11, 2405-2408.

[12] W. Song, Y. Wang, J. Qu, Q. Lin, J. Am. Chem. Soc. 2008, 130, 9654-9655.

[13] J. Schoch, M. Wiessler, A. Jaschke, J. Am. Chem. Soc. 2010, 132, 8846-8847.

[14] D. Graham, A. Enright, Curr. Org. Synth. 2006, 3, 9-17.

[15] G. Wittig, R. Pohlke, Chem. Ber. 1961, 94, 3276-3286.

[16] R. B. Turner, A. D. Jarrett, P. Goebel, B. J. Mallon, J. Am. Chem. Soc. 1973, 95, 790-792.

[17] E. M. Sletten, C. R. Bertozzi, Org. Lett. 2008, 10, 3097-3099.

[18] Y. Zou, J. Yin, Bioorg. Med. Chem. Lett. 2008, 18, 5664-5667.

[19] N. J. Agard, J. M. Baskin, J. A. Prescher, A. Lo, C. R. Bertozzi, ACS Chem. Biol. 2006, 1, 644-648.

[20] J. A. Codelli, J. M. Baskin, N. J. Agard, C. R. Bertozzi, J. Am. Chem. Soc. 2008, 130, 11486-11493.

[21] S. V. Orski, A. A. Poloukhtine, S. Arumugam, L. Mao, V. V. Popik, J. Locklin, J. Am. Chem. Soc. 2010, 132, 11024-11026.

[22] L. A. Canalle, S. S. van Berkel, L. T. de Haan, J. C. M. van Hest, Adv. Funct. Mater. 2009, 19, 3464-3470.

[23] F. Starke, M. Walther, H.-J. Pietzsch, ARKIVOC 2010, 350359.

[24] A. Kuzmin, A. Poloukhtine, M. A. Wolfert, V. V. Popik, Bioconjugate Chem. 2010, 21, 2076-2085.

[25] J. C. Jewett, C. R. Bertozzi, Chem. Soc. Rev. 2010, 39, 1272 1279.

[26] B. C. Sanders, F. Friscourt, P. A. Ledin, N. E. Mbua, S. Arumugam, J. Guo, T. J. Boltje, V. V. Popik, G.-J. Boons, J. Am. Chem. Soc. 2011, 133, 949-957.

[27] P. V. Chang, J. A. Prescher, E. M. Sletten, J. M. Baskin, I. A. Miller, N. J. Agard, A. Lo, C. R. Bertozzi, Proc. Natl. Acad. Sci. USA 2010, 107, 1821-1826.

[28] P. Kele, G. Mezö, D. Achatz, O. S. Wolfbeis, Angew. Chem. Int. Ed. 2009, 48, 344-347.

[29] A. Bernardin, A. Cazet, L. Guyon, P. Delannoy, F. Vinet, D. Bonnaffe, I. Texier, Bioconjugate Chem. 2010, 21, 583-588.

[30] M. E. Martin, S. G. Parameswarappa, M. S. O’Dorisio, F. C. Pigge, M. K. Schultz, Bioorg. Med. Chem. Lett. 2010, 20, 48054807. 
[31] E. Lallana, E. Fernandez-Megia, R. Riguera, J. Am. Chem. Soc. 2009, 131, 5748-5750.

[32] P. van Delft, N. J. Meeuwenoord, S. Hoogendoorn, J. Dinkelaar, H. S. Overkleeft, G. A. van der Marel, D. V. Filippov, Org. Lett. 2010, 12, 5486-5489.

[33] K. N. Jayaprakash, C.-G. Peng, D. Butler, J. P. Varghese, M. A. Maier, K. G. Rajeev, M. Manoharan, Org. Lett. 2010, 12, 5410-5413.

[34] T. Plass, S. Milles, C. Koehler, C. Schultz, E. A. Lemke, Angew. Chem. 2011, 50, 3878-3881.

[35] D. Castanotto, J. J. Rossi, Nature 2009, 457, 426-433.

[36] O. S. Wolfbeis, Angew. Chem. Int. Ed. 2007, 46, 2980-2982.

[37] F. Shi, J. P. Waldo, Y. Chen, R. C. Larock, Org. Lett. 2008, 10, 2409-2412.

[38] K. Sivakumar, F. Xie, B. M. Cash, S. Long, H. N. Barnhill, Q. Wang, Org. Lett. 2004, 6, 4603-4606.

[39] L. Yao, B. T. Smith, J. Aubé, J. Org. Chem. 2004, 69, 17201722.

[40] R. I. Jølck, R. H. Berg, T. L. Andresen, Bioconjugate Chem. 2010, 21, 807-810.
[41] T. Yamada, C. G. Peng, S. Matsuda, H. Addepalli, K. N. Jayaprakash, M. R. Alam, K. Mills, M. A. Maier, K. Charisse, M. Sekine, M. Manoharan, K. G. Rajeev, J. Org. Chem. 2011, 76, $1198-1211$.

[42] M. F. Debets, C. W. J. van der Doelen, F. P. J. T. Rutjes, F. L. van Delft, ChemBioChem 2010, 11, 1168.

[43] G. Godeau, C. Staedel, P. Barthelemy, J. Med. Chem. 2008, 51, $4374-4376$.

[44] J. E. MacDonald, J. A. Kelly, J. G. C. Veinot, Langmuir 2007, 23, 9543-9545.

[45] C. Li, E. Henry, N. K. Mani, J. Tang, J.-C. Brochon, E. Deprez, J. Xie, Eur. J. Org. Chem. 2010, 2395-2405.

[46] X. Jiang, M. Ahmed, Z. Deng, R. Narain, Bioconjugate Chem. 2009, 20, 994-1001.

[47] S. A. P. Guarin, D. Tsang, W. G. Skene, New J. Chem. 2007, $31,210-217$

Received: July 18, 2011

Published Online: September 19, 2011 